\title{
Intratracheal Instillation Of Coal And Coal Fly Ash Particles In Mice Induces DNA Damage And Translocation Of Metals To Extrapulmonary Tissues
}

Leon Mejia, Grethel; Machado Nascimento, Mariana; Okuro Tiemi, Renata; Silva Oliveira, Luis Felipe; Telles, Claudia; Ferraz Dias, Johnny; Niekraszewiczl Boufleur, Liana Appe; Da Silva, J; Henriques Pêgas, João Antônio; Zin Araújo, Walter.

\section{Abstract}

Continuous exposure to coal mining particles can cause a variety of lung diseases. We aimed to evaluate the outcomes of exposure to detailed characterized coal and coal fly ash (CFA) particles on DNA, lung and extrapulmonary tissues. Coal samples (COAL11 and COAL16) and CFA samples (CFA11 and CFA16) were included in this study. Intending to enhance the combustion process COAL16 was co-fired with a mixture of fuel oil and diesel oil, producing CFA16. Male BALB/C mice were intratracheally instilled with coal and CFA particles. Measurements were done $24 \mathrm{~h}$ later. Results showed significant rigidity and obstruction of the central airways only for animals acutely exposed to coal particles. The COAL16 group also showed obstruction of the peripheral airways. Mononuclear cells were recruited in all treatment groups and expression of cytokines, particularly TNF- $\alpha$ and IL-1 $\beta$ was observed. Only animals exposed to COAL16 showed a significant expression of IL6 and recruitment of polymorphonuclear cells. DNA damage was demonstrated by Comet assay for all groups. Cr, Fe and Ni were detected in liver, spleen and brain, showing the efficient translocation of metals from the bloodstream to extrapulmonary organs. These effects were associated with particle composition (oxides, hydroxides, phosphates, sulfides, sulphates, silciates, organic-metalic compounds, and polycyclic aromatic hidrocarbons) rather than their size. This work provides state of knowledge on the effects of acute exposure to coal and CFA particles on respiratory mechanics, DNA damage, translocation of metals to other organs and related inflammatory processes.

\section{Keywords}

Coal; Coal Fly Ash; DNA Damage; Inflammatory Processes; Metal Translocation. 